TAPROBANICA, ISSN 1800-427X. January, 2015. Vol. 07, No. 01: pp. 38-39.

(C) Research Center for Climate Change, University of Indonesia, Depok, Indonesia \& Taprobanica Private Limited, Homagama, Sri Lanka www.taprobanica.org

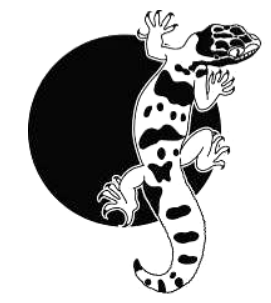

\section{Range extension of Perbrinckia scansor (Crustacea) in Sri Lanka}

Perbrinckia scansor (Ng, 1995) (see the cover page of this journal) is the only known treeclimbing freshwater crab among the 52 freshwater crab species of Sri Lanka. According to published literature, this endemic species was recorded in eleven localities (elevation range $150-960 \mathrm{~m}$ a.s.l) in the Kalu, Walawe and Gin River basins and assessed as "Least Concern" ( $\mathrm{Ng}, 1995 ; \mathrm{Ng} \&$ Tay, 2001; Bahir et al., 2005), but again this species was categorised as Endangered (Bahir \& Gabadage, 2012). This species is a habitat specialist with adults living in rainwater-filled phytotelms from about ground level up to $1 \mathrm{~m}$ above ground. We recorded the distribution of $P$. scansor from 47 localities (Fig. 1) through opportunistic observations within the period 2005-2010.

All of them were recorded from the following river basins within the island's south-western wet zone: Bentota River Basin: Yagirala, Katukitulana, $6^{\circ} 23^{\prime} \mathrm{N}, \quad 80^{\circ} 09^{\prime} \mathrm{E}, 150 \mathrm{~m}$. Gin River Basin: Beraliya Forest, Elpitiya, $6^{\circ} 16^{\prime} \mathrm{N}$, $80^{\circ} 12^{\prime} \mathrm{E}, 150 \mathrm{~m}$; Hiniduma, $6^{\circ} 18^{\prime} \mathrm{N}, 80^{\circ} 19^{\prime} \mathrm{E}$, $170 \mathrm{~m}$; Kanneliya forest, $6^{\circ} 15^{\prime} \mathrm{N}, \quad 80^{\circ} 21^{\prime} \mathrm{E}$, 240m; Kottawa-Kombala forest, $6^{\circ} 05^{\prime} \mathrm{N}$, $80^{\circ} 19^{\prime} \mathrm{E}, 25 \mathrm{~m}$; Nakiyadeniya, $6^{\circ} 08^{\prime} \mathrm{N}, 80^{\circ} 21^{\prime} \mathrm{E}$, $60 \mathrm{~m}$; Singhagala, near Sinharaja forest, $6^{\circ} 23^{\prime} \mathrm{N}$, $80^{\circ} 28^{\prime} \mathrm{E}, 700 \mathrm{~m}$; Telwatta Sanctuary, Akurala, $6^{\circ} 10^{\prime} \mathrm{N}, \quad 80^{\circ} 05^{\prime} \mathrm{E}, 5 \mathrm{~m}$. Kalu River Basin: Ambalamahena, Atweltota, $6^{\circ} 32^{\prime} \mathrm{N}, 80^{\circ} 17^{\prime} \mathrm{E}$, $190 \mathrm{~m}$; Anduragala, Ingiriya, $6^{\circ} 43^{\prime} \mathrm{N}, 80^{\circ} 4^{\prime} \mathrm{E}$, $25 \mathrm{~m}$; Bambarabotuwa, Rilagala, $6^{\circ} 30^{\prime} \mathrm{N}$, $80^{\circ} 20^{\prime} \mathrm{E}, \quad 500 \mathrm{~m}$; Batadombalena, Kuruwita, $6^{\circ} 47^{\prime} \mathrm{N}, \quad 80^{\circ} 22^{\prime} \mathrm{E}, \quad 260 \mathrm{~m}$; Delmella, Ambagaskanda, $\quad 6^{\circ} 41^{\prime} \mathrm{N}, \quad 80^{\circ} 11^{\prime} \mathrm{E}, \quad 130 \mathrm{~m}$; Dombagaskanda, Ingiriya, $6^{\circ} 44^{\prime} \mathrm{N}, \quad 80^{\circ} 09^{\prime} \mathrm{E}$, $45 \mathrm{~m}$; Dumbara Manana, Ayagama, $06^{\circ} 41^{\prime} \mathrm{N}$, $80^{\circ} 14^{\prime} \mathrm{E}, \quad 300 \mathrm{~m}$; Erakolakanda, Ayagama, $6^{\circ} 37^{\prime} \mathrm{N}, 80^{\circ} 17^{\prime} \mathrm{E}, 80 \mathrm{~m}$; Gangoda, Kuruwita, $6^{\circ} 50^{\prime} \mathrm{N}, 80^{\circ} 25^{\prime} \mathrm{E}, 850 \mathrm{~m}$; Gileemale, Ratnapura, $6^{\circ} 44^{\prime} \mathrm{N}, 80^{\circ} 28^{\prime} \mathrm{E}, 350 \mathrm{~m}$; Idangoda, Belungala, $6^{\circ} 44^{\prime} \mathrm{N}, \quad 80^{\circ} 16^{\prime} \mathrm{E}, 25 \mathrm{~m}$; Kalawana, $6^{\circ} 32^{\prime} \mathrm{N}$, $80^{\circ} 23^{\prime} \mathrm{E}, 300 \mathrm{~m}$; Kelinkanda, Kalawana, $6^{\circ} 35^{\prime} \mathrm{N}$, $80^{\circ} 18^{\prime} \mathrm{E}, 280 \mathrm{~m}$; Kiriella, Ratnapura, $6^{\circ} 10^{\prime} \mathrm{N}$, $80^{\circ} 05^{\prime} \mathrm{E}, 300 \mathrm{~m}$; Koskulana, Panapola, $6^{\circ} 44^{\prime} \mathrm{N}$, $80^{\circ} 28^{\prime} \mathrm{E}, 460 \mathrm{~m}$; Kukulegama South, $6^{\circ} 31^{\prime} \mathrm{N}$, $80^{\circ} 21^{\prime} \mathrm{E}, 410 \mathrm{~m}$; Mathugama, $6^{\circ} 31^{\prime} \mathrm{N}, 80^{\circ} 07^{\prime} \mathrm{E}$, $35 \mathrm{~m}$; Pompakela, Ratnapura, $6^{\circ} 41^{\prime} \mathrm{N}, 80^{\circ} 24^{\prime} \mathrm{E}$, $70 \mathrm{~m}$; Rusigala, Atweltota, $6^{\circ} 30^{\prime} \mathrm{N}, 80^{\circ} 19^{\prime} \mathrm{E}$, $340 \mathrm{~m}$; Seethagangula, Kuruwira trai, $6^{\circ} 49^{\prime} \mathrm{N}$, $80^{\circ} 27^{\prime} \mathrm{E}, 1120 \mathrm{~m}$; Walankanda Forest, $6^{\circ} 29^{\prime} \mathrm{N}$, $80^{\circ} 31^{\prime} \mathrm{E}, \quad 900 \mathrm{~m}$; Waranagalla, Kuruwita, $6^{\circ} 50^{\prime} \mathrm{N}, 80^{\circ} 26^{\prime} \mathrm{E}$, 550m; Weddagala, Kalawana, $6^{\circ} 27^{\prime} \mathrm{N}, 80^{\circ} 26^{\prime} \mathrm{E}, 280 \mathrm{~m}$. Kelani River Basin: Labugama, Awissawella, $6^{\circ} 15^{\prime} \mathrm{N}, \quad 80^{\circ} 11^{\prime} \mathrm{E}$, $140 \mathrm{~m}$; Maliboda, Deraniyagala, $6^{\circ} 54^{\prime} \mathrm{N}$, $80^{\circ} 25^{\prime} \mathrm{E}, \quad 325 \mathrm{~m}$; Parawalatenna, Kithulgala, $6^{\circ} 59^{\prime} \mathrm{N}, 80^{\circ} 24^{\prime} \mathrm{E}, 190 \mathrm{~m}$; Sandaraja Wanaya, Dolosbage, $7^{\circ} 09^{\prime} \mathrm{N}, 80^{\circ} 26^{\prime} \mathrm{E}, 1000 \mathrm{~m}$; Wathura, Kegalla, $7^{\circ} 11^{\prime} \mathrm{N}, 80^{\circ} 24^{\prime} \mathrm{E}, 450 \mathrm{~m}$. Mahaoya River Basin: Elangipitiya (near Debathgama), $7^{\circ} 9^{\prime} \mathrm{N}, \quad 80^{\circ} 24^{\prime} \mathrm{E}, \quad 290 \mathrm{~m}$; Narangala (near Aranayake), $7^{\circ} 7^{\prime} \mathrm{N}, 80^{\circ} 27^{\prime} \mathrm{E}, 497 \mathrm{~m}$; Urakanda, Asmadala, $7^{\circ} 11^{\prime} \mathrm{N}, 80^{\circ} 24^{\prime} \mathrm{E}, 795 \mathrm{~m}$. Mahaweli River Basin: Rambukpitiya, Nawalapitiya, $7^{\circ} 2$ 'N, $80^{\circ} 30^{\prime} \mathrm{E}, 608 \mathrm{~m}$. Nilwala River Basin: Deniyaya, $6^{\circ} 19^{\prime} \mathrm{N}, 80^{\circ} 34^{\prime} \mathrm{E}, 350 \mathrm{~m}$; Kekanadura, Matara, $5^{\circ} 59^{\prime} \mathrm{N}, \quad 80^{\circ} 35^{\prime} \mathrm{E}, \quad 80 \mathrm{~m}$; Millawa, Morawaka, $6^{\circ} 17^{\prime} \mathrm{N}, 80^{\circ} 28^{\prime} \mathrm{E}, 320 \mathrm{~m}$; Opatha, $6^{\circ} 16^{\prime} \mathrm{N}, 80^{\circ} 24^{\prime} \mathrm{E}, 215 \mathrm{~m}$. Walawe River Basin: Caledonia, Morningside, $6^{\circ} 44^{\prime} \mathrm{N}, 80^{\circ} 37^{\prime} \mathrm{E}$, $800 \mathrm{~m}$; Rakwana, $6^{\circ} 30^{\prime} \mathrm{N}, \quad 80^{\circ} 35^{\prime} \mathrm{E}, \quad 400 \mathrm{~m}$; Walaboda, Balangoda, 64' $\mathrm{N}, 80^{\circ} 36^{\prime} \mathrm{E}, 960 \mathrm{~m}$.

Clearly $P$. scansor demonstrates a much wider distribution (elevation 5-1120 m a.s.l) than previously reported, though restricted to the wet zone. Approximately $80 \%$ of Sri Lankan freshwater crab species are restricted to the island's rain forest at the south-western wet zone, which includes the central mountains (Bahir et al., 2005). Species that require special habitat have a greater tendency to become extinct when changes occur in the environment (Isik, 2011). P. scansor is such a species and the habitats of this freshwater crab should be carefully monitored and managed to conserve the species. 


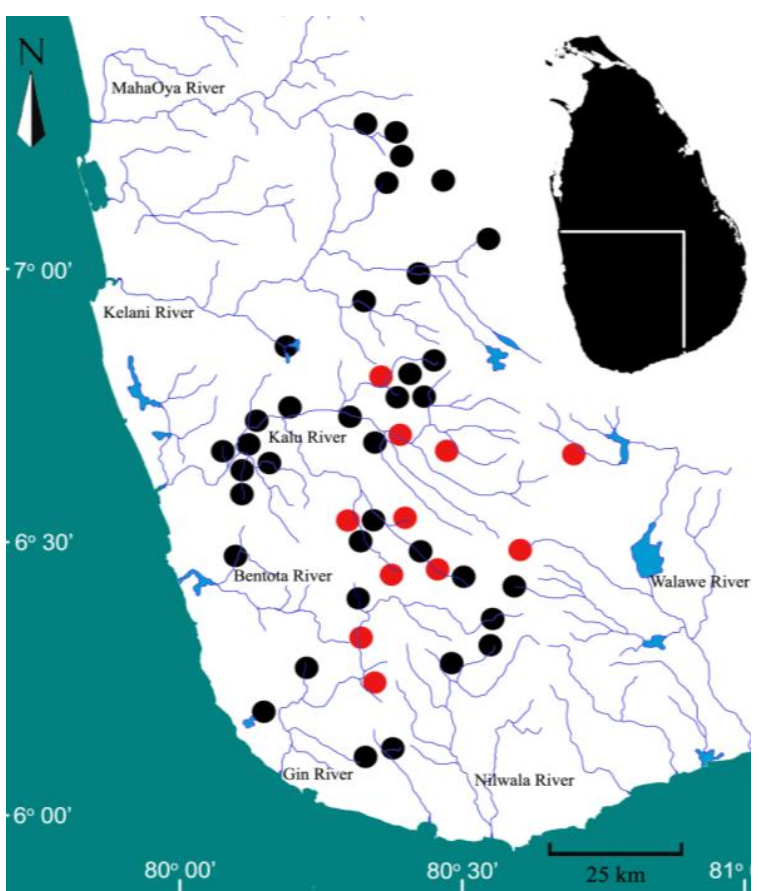

Figure 1: Current (black) and previous (red) distribution of Perbrinckia scansor in Sri Lanka.

During the survey we found $12(\sim 25 \%)$ tree holes utilized by both male and female, and the rest of $35(\sim 75 \%)$ holes were utilized by males only. It is interesting we cannot find holes were utilized by only females, even females was recorded $1 \mathrm{~m}$ above ground level $(\mathrm{Ng}, 1995) .5$ $(\sim 10 \%)$ tree holes were shared by either tarantula (Poecilotheria sp.) or microhylid frog (Ramanella nagaoi). According to our observation $P$. scansor preferred rainwater-filled phytotelms of the tress of the following genera Shorea (Dipterocarpaceae), Artocarpus, (Moraceae), Dillenia (Dilleniaceae), Garcinia (Clusiaceae), Myristica (Myristicaceae), and Gyrinops (Thymelaeaceae). These trees were growing up to $20 \mathrm{~m}(\mathrm{DBH} 18-34 \mathrm{~cm})$ with $60 \%-80 \%$ of canopy cover. The most of the tree holes contained leaf litters, but not found any mosquito larvae or frog tadpoles. The tree holes were 15-28 $\mathrm{cm}$ deep and the diameter measured 4-13 cm. All the crabs were recorded from the holes between 1 and $5 \mathrm{~m}$ above the ground level. It was very difficult to locate them during the day time as they are hiding inside the hole, but at night they come out from the hole and moving on the surface of tree trunks. We observed few females on the ground with the newborns carried on during February and March, but never found in the tree holes. Large females are hiding under highly shaded rock crevices in the stream; rarely males too can observe on the ground, but only at night.
Deforestation is identified as a major growing threat as rainwater-filled phytotelms are dried easily when the shade (canopy) disappears. Many road kills were observed during past decade. Natural predators are southern coucal (Centropus parroti), white-throated kingfisher (Halcyon smyrnensis), Sri Lanka grey hornbill (Ocyceros gingalensis) and otter (Lutra lutra).

\section{Acknowledgements}

We thank M. M. Bahir for providing literature; D. Kandamby for providing locality data in Rambukpitiya; the field staff of DF \& DWC and YZA members for the support in the field.

\section{Literature Cited}

Bahir M. M. and D. E. Gabadage, 2012. Taxonomy and Conservation status of the Freshwater crabs (Crustacea: Decapoda) in Sri Lanka. In: D. K. Weerakoon \& S. Wijesundara (Eds.). The National Red List 2012 of Sri Lanka: Conservation Status of the Fauna and Flora. Ministry of Environment, Colombo: 58-64.

Bahir M. M., P. K. L. Ng, K. Crandall, and R. Pethiyagoda, 2005. Conservation assessment of the freshwater crabs of Sri Lanka. The Raffles Bulletin of Zoology, Supp. 12: 121-126.

Isik, K., 2011. Rare and endemic species: why are they prone to extinction?. Turkish Journal of Botany, 35: 411-417.

Ng, P. K. L., 1995. Ceylonthelphusa scansor, a new species of tree-climbing crab from Sinharaja Forest in Sri Lanka (Crustacea: Decapoda: Brachyura: Parathelphusidae). Journal of South Asian Natural History, 1: 175-184.

Ng, P. K. L. and F. W. M. Tay, 2001. The freshwater crabs of Sri Lanka (Decapoda: Brachyura: Parathelphusidae). Zeylanica, 6: 113199.

Submitted: 13 Mar. 2014, Accepted: 18 May 2014 Section Editor: M. M. Bahir

D. E. Gabadage ${ }^{1}$, U. S. C. Udagedara ${ }^{2}$ \& D. M. S. S. Karunarathna ${ }^{3}$

\footnotetext{
${ }^{1}$ Taprobanica Nature Conservation Society, 150/6 Stanley Thilakarathne Mw., Nugegoda, Sri Lanka E-mail: degabadage@gmail.com

${ }^{2}$ National Cleaner Production Center, 251/30, Kirula Road, Narahenpita, Colombo 5, Sri Lanka ${ }^{3}$ Nature Exploration and Education Team, B-1/G-6, Soysapura, Moratuwa 10400, Sri Lanka
} 